\title{
Use of extracts of sunflower-seed oil (Helianthus annus L.) for the treatment of cutaneous injuries in equine metatarsus: a case report
}

\author{
COELHO, C.S. ${ }^{1 *}$; GAMA, J.A.N. ${ }^{1}$; OLIVEIRA JÚNIOR, L.A.T. ${ }^{1}$; SILVA, B.S.F. ${ }^{2}$; SOUZA, V.R.C. ${ }^{1}$; ENDRINGER, \\ D.C. ${ }^{2}$; LENZ, D. ${ }^{1}$ \\ ${ }^{1}$ Faculdade de Medicina Veterinária e Zootecnia, ${ }^{2}$ Faculdade de Farmácia, Centro Universitário Vila Velha (UVV), \\ Rua Comissário José Dantas de Melo, 21, CEP: 29102-770, Vila Velha-Brazil *Clarisse.coelho@uvv.br
}

\begin{abstract}
This study describes an eighteen-year-old filly after an injury in the region of the dorsal left metatarsus, admitted to veterinary assistance. In addition to the normal treatment, which was characterized by cleaning and topical application of povidone-iodine, sunflower-seed oil was applied locally in order to improve and fasten wound healing. Macroscopic and clinical improvements of the wound healing were observed. The preliminary chemical and physical analyses have shown the stearic acid as the main component. The results suggest that the sunflower-seed oil enable a faster wound healing in horses.
\end{abstract}

Key words: equines, sunflower-seed oil, alternative treatment, wound healing

\begin{abstract}
RESUMO: Uso do óleo de semente de girassol (Helianthus annus) no tratamento de lesões cutâneas no metatarso de um equino: relato de caso. $O$ presente relato se refere a uma potra de 18 meses de idade que foi encaminhada a atendimento veterinário após sofrer grave lesão na região dorsal do metatarso esquerdo. Além do tratamento convencional, caracterizado pela limpeza e aplicação tópica de iodo-povidine, foi aplicado no local óleo de semente de girassol na tentativa de melhorar e acelerar a cicatrização da ferida. Foi observada a melhora clínica e macroscópica da lesão. Análises preliminares químicas e físicas demonstraram o ácido esteárico como principal componente do óleo usado. Os resultados sugerem que o óleo de semente de girassol é capaz de acelerar e melhorar a qualidade de cicatrização em feridas de equinos.
\end{abstract}

Palavras-chave: equinos, óleo de semente de girassol, terapias alternativas, cicatrização de feridas

Wounds can be purposely generated during a surgery or may result from an accident (Cochrane, 1997; Garro et al., 2006; Stavrou, 2008). Any wound, regardless of the cause, impacts the blood supply to the affected tissue (Stavrou, 2008). Furthermore, inflammatory substances accumulate in the injured tissue and may lead to different degrees of contamination, resulting in infection (Magalhães et al., 2008). The subsequent healing of the injury itself is a dynamic process in which cellular, humoral, and molecular factors interact to achieve a reparation or regeneration of the altered tissue (Banks, 1992). Therefore, this ability of an organism to heal wounds allows that surgeries can be done in animals and men with subsequent primary healing (Magalhães et al., 2008). The process of wound healing begins immediately after the formation of the wound and combines exudation, proliferation and maturation. During proliferation, keratinocytes, fibroblasts and endothelial cells migrate into the altered tissue and cause both epithelization and the generation of granulation tissue. During the maturation phase, excessive collagen is degraded by proteolytic enzymes (Bertone, 1989; Mori et al., 2004). Depending on the type, localization and contamination of the wound, a distinction is made between primary and secondary healing (Kent Lloyd, 1992). Wounds have a significant impact on the use of horses (Stashak, 1994; Cochrane, 1997).

Physiological and environmental factors influence the healing process and affect the duration and quality of wound healing. Many isolated natural products and medicinal plants with a potential antiinflammatory effect could be used to promote wound healing (Falcão et al., 2005). Brazil possesses a broad native plant biodiversity, along with plants that were introduced by African and European immigrants (Brandão et al., 2009). A large number of those species

Recebido para publicação em 12/10/2010

Aceito para publicação em 01/07/2011

Rev. Bras. PI. Med., Botucatu, v.14, n.1, p.125-129, 2012. 
are considered medicinal plants and are widely used in folk medicine to treat different diseases processes, as inflammatory conditions (Falcão et al., 2005). According to the World Health Organization, $80 \%$ of the world population use plants as medicine (Hostettmann \& Marston 2002; WHO, 2002; Maciel et al., 2002). However, for many medicinal plants the pharmacological effect remains not yet evaluated or unknown (Falcão et al., 2005).

There are several reports describing the use of medicinal plants to improve wound healing (Foro, 1988; Sanchez Neto et al., 1993; Eurides et al., 1996; Coelho et al., 2001; Capo et al., 2004; Falcão et al., 2005; Garro et al., 2006; Perazzo et al., 2007; Possa et al., 2007; Santos et al., 2007; Perazzo et al 2008; Mazid et al., 2009). The oil of Copaiba tree (Eurides \& Mazzanti, 1995; Possa et al., 2007), papain (Sanchez Neto et al., 1993), the petroleum ether extract of Polygonum barbatum var. barbata (Mazid et al., 2009) are examples of active medicinal plants and natural products popularly used in the wound healing process.

Many studies have described that in horses several drugs could cause irritation or an excessive granulation, during the wound healing process (Bertone, 1989; Kent, 1992; Corsi et al., 1994; Cochrane, 1997). However, some medicinal plants have been reported as effective in the wound healing, with low or not observed side effect. An ointment of extracts of wheat (Triticum vulgare L.) showed an accelerated wound healing in equines (Souza et al., 2006). Martins et al. (2003) compared the wound healing effect of barbatiman (Stryphnodendron barmatiman), marigold (Calendula officinalis) and confrey (Symphytum officinale), and barbatiman yielded the best results.

In Europe, the sunflower (Helianthus annus L.) was used as ornamental, being immortalized by Van Gogh in his famous paintings, and also as a medical plant since the 18th century (Mackenbach, 2004). During the 19th century, the sunflower began to be known as oil plant (Mackenbach, 2004). Sunflower oil can be produced industrially or manually. However, it is important to use only the black nuclei (Ortonne \& Clevy, 1994). In general, all the oil used in salads or diets can be used to the local treatment of burnings (Zanoschi et al., 1991; Vasconcelos, 1997). The sunflower oil is basically composed by fatty acids, the steraric acid being the main component, followed by a large proportion of unsaturated fatty acids, mainly oleic and linolenic acids (Erbas \& Baydar, 2007).

The use of fatty acids to treat skin problems is studied since 1929, after several studies had reported on faster wound healing, due to changes in diet (Burn \& Burn, 1930; Sinclair \&
Basnayeke, 1954). Linn \& Shepherd (1936) and Vantorp (1974) observed a healing effect on skin wounds after local application of sunflower oil.

This case report describes a treatment of accidental wounds of a Mangalarga Marchador female horse with commercial sunflower oil, as an addition to the normal treatment. At the time of admission to the veterinary assistance, the patient was 18 months old. It is worth to highlight that the wound was set accidentally; therefore the wound was not symmetric. The WHO (World Health Organization, 2005) emphasizes the NECESSITY to evaluate and register the traditional medicine and the complementary and alternative medicine. As soon as the sunflower treatment was communicated, a previous report and sort report describing the treatment was submitted to an ethical committee, being approved.

The medical history reported an accident of the animal through a barbed wire in the enclosure. The clinical examination revealed the presence of a lesion characterized by the absence of skin in the dorsal left metatarsus, close to the digital extensor tendon. After an initial treatment by the veterinary in charge, the owner was trained on how to daily wash and take care of the wound. The daily treatment consisted of washing and applying locally an iodine solution, keeping the wound covered with a bandage. In addition, a topical application of gauze embedded with commercial sunflowerseed oil was recommended, following the popular knowledge cited also by the owner who used to apply it over skin wounds of humans with good results and low cost. During the first days of treatment, the bandage was supported with a splint made of polyvinyl chloride (PVC). Later, the PVC was replaced by standard gauze. The treatment with the sunflower seed oil alone took 90 days. Macroscopically, the success of the treatment could be easily verified. After 60 days, only a slight formation of granulation tissue was recorded (Figure $1 \mathrm{~A}$ ). This initial development of exuberant granulation tissue was controlled by the topical application of formaldehyde (10\%) on the wound. Although within three months the wound did not achieve the state of restitutio ad integrum an enhanced wound healing could be observed by the veterinarians in charge (Figure $1 \mathrm{~B}$ ). At this time, a salve with zinc oxide was added to the treatment because of its astringent and antiseptic effects After eight months of veterinary treatment (association of sunflower seed oil and zinc oxide), the wound of the Mangalarga Marchador horse had healed and the patient was free of lameness (Figure $1 \mathrm{C})$, suggesting that the topical application of sunflower-seed oil had a good influence on the 
wound healing in this patient. The sunflower oil was used in the wound treatment of lambs (Marques et al., 2004) and similar results were found out. The presence of essential fatty acids was suggested to improve the inflammatory response to injury (Marques et al., 2004). The effect of the fatty acids on the biochemical processes that precede the fibroplasias and a stimulation of neovascularisation by essential fatty acids were observed in this study (Marques et al., 2004). As cited before, the mainly fatty acids of sunflower are the stearic, oleic and linoleic acids (Erba ${ }^{\circ} \&$ Baydar, 2007). The linolenic acid is an essential fatty acid with 18 carbon atoms and precursor of arachidonic acid (Erba ${ }^{\circ} \&$ Baydar, 2007). The arachidonic acid is metabolized by lipoxygenase and cyclooxygenase; leukotrienes, prostaglandins and thromboxanes are some of the proinflammatory metabolites (Ortonne \& Clevy, 1994; Marques et al., 2004). The proinflammatory properties of these substances cause local neovascularization, cellular migration, and synthesis of extracellular matrix (Corsi et al., 1994). In addition, for linolenic acid an impact on the cellular proliferation could be detected (Marques et al., 2004; Magalhães et al., 2008). Other (Marques et al., 2004; Magalhães et al., 2008) described that the effects of linolenic acid are its participation in the inflammatory process through the stimulation of neutrophils, and antibacterial mechanisms. Magalhães et al. (2008) studied the effects of linolenic acid, soy lecithin, retinol and tocopherol in terms of their contribution to wound healing in rats. Rocha et al. (2004) compared the effect of sunflower-seed oil and chain on wound healing in rats. With both substances, a positive effect on the healing process was noted.

Sunflower oil was purchased from a local grocery store in Vila Velha, ES. The UV/Vis spectrum was determined using a spectrophotometer (T80 +, PG Instruments) with a tungsten-deuterium lamp used as light source. The initial arrays were carried out in a range of 190 to $650 \mathrm{~nm}$, later arrays in a spectrum from 190 to $450 \mathrm{~nm}$. Oleic acid $\left(20 \mathrm{mg} \mathrm{mL}^{-1}\right)$, stearic acid $(20$ $\left.\mathrm{mg} \mathrm{mL}^{-1}\right)$ and palm acid methyl $\left(20 \mathrm{mg} \mathrm{mL}^{-1}\right)$ were used as standards. The analysis was in accordance with the proposed methods of the Association of Official Analytical Chemists (AOAC, 1995). Investigated parameters included density, acid value, the level of lipids and saponification. The chemical fingerprint was obtained using thin layer chromatography (TLC) under a silica gel, with mobile phase dichloromethane: ethyl acetate (2:1), followed by detection with anisaldhyde-sulfuric acid reagent. The standards were oleic acid, stearic acid and palm acid methyl. The performed physicalchemical analyses approach to evaluate the features of the applied oil was done after the treatment. The measured density of the oil $(0.9157$ $\mathrm{g} \mathrm{mL}^{-1}$ ) is in accordance with the literature (OstriæMatijaseviæ et al., 1980; Safarov \& Abdukhamidova, 1995; Portas, 2001). The lipids index $83.9 \pm 2.6 \%$ shows that around $16 \%$ of the used substance are hydrosoluble. The acid index and saponification showed that the oil has a high concentration of free fatty acids, a factor which should have positive effects on the pharmacological effect of the sunflower oil. It is noteworthy to mention that the $\mathrm{pH}$ of skin wounds in the beginning is in the acidic range, a $\mathrm{pH}$ in which the acids are liposoluble. During the process of healing, however, the $\mathrm{pH}$ rises to values up to eight, which likely negatively impacts the affectivity of the oil (Schneider et al., 2007; Theoret, 2008).

The overlapping of UV profile of the standards and the sunflower oil suggested that the
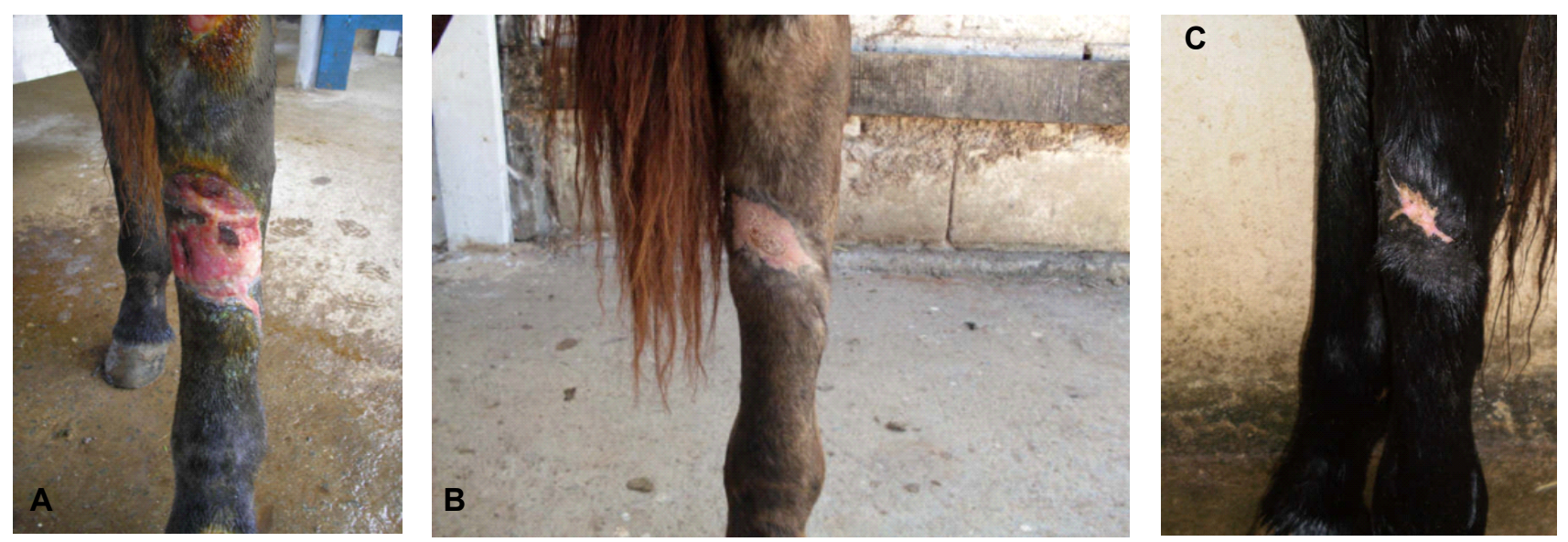

FIGURE 1. The wound of the patient at the metatarsus. A. After 60 days of treatment with sunflower seed oil. B. After 90 days of treatment only with sunflower seed oil $\mathbf{C}$. Eight months after starting treatment demonstrating a complete healing. 


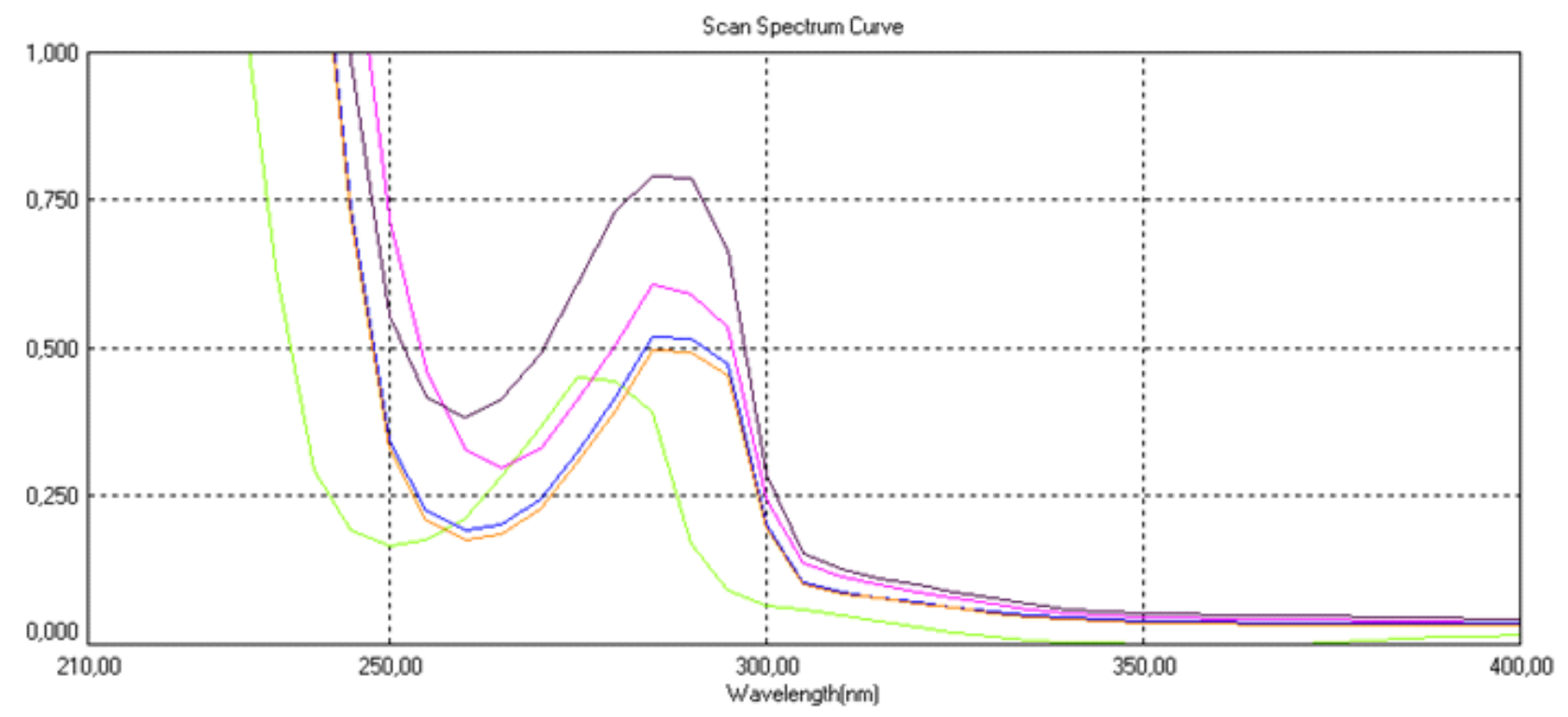

FIGURE 2. UV range from 190 to $450 \mathrm{~nm}$ with oil from sunflower seeds (gray line), oleic acid (green line), stearic acid (pink line) and palm methyl acid (blue and orange lines)

stearic oil is most similar to sunflower oil, both had an absorption maximum from 260 to $285 \mathrm{~nm}$ (Figure 2). The TLC chromatogram (data no shown) revealed the presence of similar compounds to the stearic acid, and the spot referent to oleic acid was not observed in the sunflower oil.

After these results we can conclude that the sunflower-seed oil (Helianthus annus) can positively contribute to the equine wound healing. In addition to this fact, another advantage of using sunflower oil is certainly a decrease in the financial burden. Despite favorable results in this study, further studies should be conducted to prove the effects of sunflower seed oil on wound healing.

\section{REFERENCE}

A.O.A.C. (Association of Official Analytical Chemists) Official Methods of Analysis. Arlington: Patricia Cunniff, 1995. p.17.

BANKS, W.J. Histologia veterinária aplicada. São Paulo: Manole, 1992. 629p.

BERTONE, A.L. Management of exuberant granulation tissue. Veterinary Clinics North America, v.5, n.3, p.55162, 1989.

BURN, G.O.; BURN, M.M. The nature of fatty acids essential in nutrition. Journal of Biological Chemistry, v.86, p.587-621, 1930.

CAPO, C.J.I.T. et al. Efecto cicatrizante de la crema de extracto etanólico de cera de caña. Revista Cubana de Plantas Medicinales, v.9, n.2, s.p., 2004.

COCHRANE, C.A. Models in vivo of wound healing in the horse and the role of growth factors. Veterinary Dermatology, v.8, p.259-72, 1997.

COELHO, C.O.C. et al. Biopolímero produzido a partir da cana-de-açúcar para cicatrização cutânea. Acta Cirurgica Brasileira, v.17, n.1, p.11-3, 2001.

CORSI, R.C.C. et al. Cicatrização de feridas: revisão de literatura. Revista Brasileira de Cirurgia, v.84, p.17-24, 1994. ERBAS, S.; BAYDAR, H. Defoliation effects on sunflower (Helianthus annus L.) seed yield and oil quality. Turk Journal of Biology, v.31, p.115-8, 2007.

EURIDES, D. et al. Morfologia e morfometria da reparação tecidual de feridas cutâneas de camundongos tratadas com solução aquosa de barmatimão (Stryphynodendron barmatiman). Revista da Faculdade de Zootecnia, Veterinária e Agronomia, v.2, n.1, p.30-40, 1996.

FORO, A.C.M. Plantas medicinais: um auxílio para a cicatrização. Acta Paulista de Enfermagem, v.1, n.3, p.739, 1988.

GARRO, I.C. et al. Extrato de Passiflora edulis na cicatrização de feridas cutâneas abertas em ratos: estudo morfológico e histológico. Acta Cirurgica Brasileira, v.21, n.3, p.55-65, 2006.

GLASGOW, W.C.; ELING, G.T. Epidermal growth factor simulates linoleic acid metabolic in BAB/C 3T3 fibroblast. Molecular Pharmacology, v.38, p.503-10, 1990.

HOSTETTMANN, K.; MARSTO, A. Twenty years of research into medicinal plants: Results and perspectives Phytochemistry Review, v.1, n.3, p.275-85, 2002. KENT LLOYD, K.D. Wound healing. In: AUER, J.A. Equine surgery. Philadelphia: W. B. Saunders, 1992. p.38-45.

LINN, D.S.; SHEPHERD, M.I. Evolution of vitamin F. Drug Cosmetic Industrial, v.38, p.329-31, 1936.

MACIEL, M.A.M. Plantas medicinais: a necessidade de estudos multidisciplinares. Química Nova, v.25, n.3, p.429-38, 2002.

MAGALHÃES, M.S.F. et al. Effect of a combination of medium chain triglycerides, linoleic acid, soy lecithin and vitamins $A$ and $E$ on wound healing in rats. Acta Cirurgica Brasileira, v.23, n.3, p.262-9, 2008.

MARQUES, S.R. et al. The effects of topical application of 
sunflower-seed oil on open wound healing in lambs. Acta Cirurgica Brasileira, v.19, n.3, p.196-205, 2004. MARTINS, O.S. et al. Comparação entre fitoterápicos de uso tópico na cicatrização de pele em equinos. Archives of Veterinary Science, v.8, n.2, p.1-7, 2003.

MAZID, M.A. et al. Antinociceptive, anti-inflammatory and diuretic properties of Polygonum barbatum (L.) Hara var. barbata. Brazilian Journal of Pharmacognosy, v.19, n.3, p.749-54, 2009.

MORI, R. et al. Impairment of skin wound healing in $\beta$ 1,4-galactosyltransferase-deficient mice with reduced leukocyte recruitment. American Journal of Pathology, v.164, n.4, p.1303-14, 2004.

ORTONNE, J.P.; CLEVY, J.P. Physiology of cutaneous cicatrization. La Revue du praticien, v.44, n.13, p.17337, 1994.

OSTRIÆE-MATIJASEVIÆE, B.; TURKULOV, J.; KARLOVIÆE, $D$. Quality of sunflower oil bleached during deodorization. Journal of American Oil Chemistry Society, v.57, n.10, p.323-5, 1980.

PERAZZO, F.F. Anti-inflammatory and analgesic activities of Hypericum brasiliense (Willd) standardized extract.

Revista Brasileira de Farmacognosia, v.18, n.3, p.3205, 2008.

PERAZZO, F.F. Comparative anti-inflammatory and antinociceptive effects of terpenoids and an aqueous extract obtained from Croton cajucara Benth. Revista Brasileira de Farmacognosia, v.17, n.4, p.521-8, 2007. PORTAS, A.A. Produção artesanal de óleo de girassol. Campinas: Cati, 2001. p.2

POSSA, D.V. et al. Contribuição ao estudo morfométrico de cicatrização de feridas cutâneas de segunda intenção com óleo de copaíba, em ratos. In: SALÃO DE INICIAÇÃO CIENTÍFICA, 5., 2007, Ji-Paraná. Proceedings... JiParaná: Ciência \& Consciência, 2007. On line.

ROCHA, R.P. et al. Estudo comparativo do processo de cicatrização com o uso do óleo de semente de girassol e triglicérides de cadeia-média: modelo experimental em ratos. Scientia Medica, v.14, n.3, p.203-8, 2004.
SAFAROV, M.M.; ABDUKHAMIDOVA, Z. Calculation of the density of solutions (sunflower oil $+n$-hexane) over a wide range of temperatures and pressure. Journal of Engineering of Physics and Thermophysics, v.68, n.5, p.640-3, 1995.

SANCHEZ NETO, R.; BARONE, B.; TEVÊS, D.C. Aspectos morfológicos e morfométricos da reparação tecidual de feridas cutâneas de ratos com e sem tratamento com solução de papaína a $2 \%$. Acta Cirurgica Brasileira, v.8, n.1, p.18-23, 1993.

SANTOS, V.L. Pharmacological studies of ethanolic extracts of Maytenus rigida Mart (Celastraceae) in animal models. Revista Brasileira de Farmacognosia, v.17, n.3, p.336-42, 2007.

SCHNEIDER, L. et al. Influence of $\mathrm{pH}$ on wound-healing: a new perspective for wound-therapy? Archives of Dermatological Research, v.298, n.9, p.413-20, 2007. SINCLAIR, H.M.; BASNAYEKE, V. Skin permeability in deficiency of essential fatty acids. Journal of Physiology, v.126, p.55-6, 1954.

SOUZA, D.W. et al. Ensaio da aplicação de creme à base de Triticum vulgare na cicatrização de feridas cutâneas induzidas em equinos. Revista Brasileira de Plantas Medicinais, v.8, n.3, p.9-13, 2006.

STASHAK, T.S. Principles of wound healing. In: STASHAK, T.S. Equine wound management. London: Lea \& Febiger, 1994. p.1-18.

VANTORP, D.A. Essential fatty acids e prostaglandins. In: INTERNATIONAL CONGRESS PURE APPLIED CHEMISTRY, 24., 1974, London. Proceedings... London: Butterworth, 1974. p.117.

VASCONCELOS, E. The usefulness of topical application on of essential fatty acids to prevent pressure ulcers. Ostomy/Wound Management, v.43, p.48-52, 1997. WHO. World Health Organization. Traditional Medicine Strategy 2002 - 2005. Geneva: World Health Organization, 2002. 74p.

ZANOSCHI, C. et al. The efficiency of some natural drugs in the treatment of burns. Revista Medico Chirurgicala, v.95, p.63-5, 1991. 